\title{
Muscle Dysmorphia: A Comparison Between Competitive Bodybuilders and Fitness Practitioners
}

\author{
Stefania Cella, Mara lannaccone and Paolo Cotrufo*
}

\author{
Observatory on Eating Disorders, Department of Psychology, Second University of Naples (SUN), Italy
}

\begin{abstract}
Objective: The primary aim of this study was to investigate the features of Muscle Dysmorphia and other body image-related concerns in a sample of competitive male bodybuilders. Method: We screened 217 male athletes, 119 bodybuilders and 98 fitness practitioners, recruited in 12 gymnasiums in Southern Italy, by means of an ad hoc sociodemographic schedule, the Muscle Dysmorphia Inventory (MDI) and the Muscle Appearance Satisfaction Scale (MASS).

Results: Twenty one of the bodybuilders (17.6\%) show high levels of preoccupation and dissatisfaction with their muscularity, $45.4 \%(\mathrm{~N}=54)$ a marked dependence on bodybuilding; 35.3\% ( $\mathrm{N}=42)$ follow a high-protein diet and $35.3 \%$ $(\mathrm{N}=42)$ used vitamin supplements to improve their weightlifting performances and favor post-training physical recovery. In addition, forty-three (36.1\%) also report use of substance while nine subjects (7.6\%) declare to avoid situations in which their body might be seen or manifest high levels of distress when this happens. The ANCOVA (Exercise Frequency per Week as a covariate) results indicate that bodybuilders, compared to fitness practitioners, report significant elevations in all measures. Moreover, considering only the bodybuilders sample, who report a regular use of substance scored higher in Dietary Behavior, Body size-symmetry, Physique Protection, Supplement Use MDI scales and on Body building Dependence, Muscle Checking and Injury MASS subscales.
\end{abstract}

Discussion: Our findings seem to suggest that the practice of the bodybuilding is associated to the proposed criteria of muscle dysmorphia if compared with regular fitness practice. In particular, we found that a regular use of substance was associated with greater dissatisfaction with muscularity.

Keywords: Muscle Dysmorphia, drive for muscularity, bodybuilding, anabolic steroids, survey descriptive study.

\section{INTRODUCTION}

The last twenty years have witnessed a growing interest in a "new" primarily male pathology, i.e. Reverse Anorexia (RA) [1]. The main psychopathological characteristic of this clinical picture, later named Muscle Dysmorphia (MD) [2] is the presence of a pathogenic idea whereby the subject is never satisfied with his muscularity, despite the presence of muscle hypertrophy. This pathological preoccupation leads to a perseverance in attempting to increase the muscular mass through physical exercise, namely weightlifting [3-4], the adoption of dysfunctional eating behaviours such as high-protein diets and strategies to counter body fat increase [5], the use of nutritional supplements or anabolic steroids [1, 6-7]. The latter behaviour seems to be present in $46 \%$ of subjects with MD [8] and in $44 \%$ of bodybuilders [9]. In addition to the complications deriving from the intake of these substances, the subjects also show impaired social and occupational functioning in association with their condition [10-11]. These men may neglect important social and family relationships or occupational activities in order to spend more time at the gym [2] or often they refuse to be seen in public because they believe that they will appear too small and weak [1].

*Address corresponding to this author at the Department of Psychology, Second University of Naples (SUN), Viale Ellittico, 3181100 Caserta, Italy; Tel: (+39) 0823-274773; Fax: (+39) 0823-274773; E-mail: paolo.cotrufo@unina2.it

E-ISSN: 1929-5634/12
It has been suggested that bodybuilders may be high-risk group for the development of muscle dysmorphia [12-13], and that this may be associated with unhealthy behaviours such as anabolic steroid abuse [9]. In a study by Lantz, Rhea \& Cornelius [14], a sample of competitive bodybuilders, compared to power lifters, were more likely to engage in features associated with MD. In a research carried out by Mangweth et al. [15], a group of 28 male bodybuilders was compared to a group of 30 males diagnosed with Eating Disorder (ED) and a control group $(\mathrm{N}=30)$. The results obtained shown preoccupation for physical appearance as well as psychological characteristics that are typically associated with EDs, which made the sample of bodybuilders more similar to the group of males with mental anorexia than to the control males. The significant difference was that the bodybuilders, as compared to the male anorexics, focused their attention on the development of muscular mass rather than on weight loss. Babusa \& Tury [16] emphasize the relationship between MD symptoms, eating disorder characteristics and steroid use also in the CentralEastern European region.

Although other studies aimed at monitoring comorbidity between muscle dysmorphia and eating disorders highlight the resemblance of some traits [8, 13, 17-23], conceptually, MD is included in the Body Dysmorphic Disorder, and the concern for not being sufficiently muscular is assumed to be determined by a distorted perception of one's body image [2, 8, 24]. 
It should be borne in mind that MD is not currently included in the Diagnostic and Statistical Manual of Mental Disorders - IV (DSM-IV; 25), which has made the studies aimed at monitoring its epidemiology, clinical description and comorbidity not completely reliable. An attempt to systematise the diagnosis of MD was made by Pope et al. [2].

On the basis of these observations, the aims of this study were to investigate psychological characteristics and the features of muscle dysmorphia in a sample of competitive bodybuilders and to offer preliminary evidence about its frequency, that may be useful for further research and preventive actions.

\section{METHOD}

\section{Participants}

The sample consisted of 217 male athletes, 119 bodybuilders and 98 non-bodybuilders, recruited in 12 gymnasiums in Southern Italy. The groups were similar in terms of educational levels $\left(\chi_{(1)}^{2}=.697 ; p=.404\right)$ and in the mean age $\left(F_{(1,215)}=.042 ; p=.838\right)$, while there were time spend at the gym differences $\left(\chi_{(1)}^{2}=99.940\right.$; $\mathrm{p}=.000$ ) (Table 1).

Bodybuilders were defined as athletes who worked out at least 3-6 hours per week with free weights and/or machines. Each trainer was also asked to identify if they were competitive bodybuilders.

\section{Procedure}

All subjects were fully informed and provided informed consent. Questionnaires were completed during regular training and under the supervision of researchers, present at all times to answer all possible queries and clarify items when needed.

\section{Assessment Instruments}

\section{Demographic Information}

An ad hoc socio-demographic form was performed to asses subject's age, weight and height, education, current occupation, family composition, father's and mother's education, as well as the time the subject devotes to physical activity.

\section{Muscle Dysmorphia Inventory}

The Muscle Dysmorphia Inventory (MDI; 14) is a 27-item inventory, designed to identify the psychological and behavioural characteristics associated with Muscle Dysmorphia. The MDI yields five scale (Dietary Behavior, Body size-symmetry, Bodybuilding Dependence, Physique Protection, Supplement Use) and appears to possess acceptable psychometric properties.

\section{Muscle Appearance Satisfaction Scale}

The Muscle Appearance Satisfaction Scale (MASS; 26) is a brief, 19-item self-report measure for the assessment of the cognitive, affective and behavioral dimensions of the construct of Muscle Dysmorphia. All sub-scale (Bodybuilding Dependence, Muscle Checking, Substance Use, Injury, Muscle Satisfaction) have been found to have acceptable internal consistency, test-retest reliability, construct validity, and a stable factor structure replicated across samples of male weight lifters.

\section{Statistical Analyse}

Categorical variables were compared using $\chi^{2}$ analyse, while group differences in MDI and MASS scores were examined using multivariate analysis of covariance (MANCOVA), with "Exercise Frequency per Week" as a covariate. Significant multivariate findings were followed by analysis of covariance (ANCOVA).

Finally, we reasoned that time spent at the gym may moderate the relationship between substance use and scores on the MDI and MASS scales. Considering only the bodybuilders sample, a 2 (Substance Use) X 2 (Exercise Frequency per Week) analyses of variance (ANOVA) was performed across all measures.

The values were considered statistically significant at $\alpha<0.05$.

\section{RESULTS}

Four (3.4\%) bodybuilders seem to meet the proposed diagnostic criteria for Muscle Dysmorphia. $17.6 \%(\mathrm{~N}=21)$ show high levels of preoccupation and dissatisfaction with their muscularity, $45.4 \%(\mathrm{~N}=54)$ a marked dependence on bodybuilding; $35.3 \%(\mathrm{~N}=42)$ follow a high-protein diet and $35.3 \% \quad(\mathrm{~N}=42)$ used vitamin supplements to improve their weightlifting performances and favor post-training physical recovery. In addition, forty-three $(36.1 \%)$ also report use of substance while nine $(7.6 \%)$ declare to avoid situations in which their body might be seen or manifest high levels of distress when this happens (Table $\mathbf{1}$ ).

The multivariate procedure reveals a significant effect of "Group" on the six MDI scales (Wilk's $\left.\operatorname{lambda}_{(2,214)}=.643 ; p=.000\right)$ and on all the MASS 
Table 1: Socio-Demographic Characteristics and the Cut-Off Values at the Muscle Dysmorphia Inventory (MDI) Scales for Bodybuilders ( $\mathrm{N}=119)$ and Non Bodybuilders $(\mathrm{N}=98)$

\begin{tabular}{|c|c|c|}
\hline & $\begin{array}{l}\text { Bodybuilders } \\
\qquad(\mathrm{N}=119)\end{array}$ & $\begin{array}{c}\text { Non-Bodybuilders } \\
(\mathrm{N}=98)\end{array}$ \\
\hline & \multicolumn{2}{|c|}{ Mean (SD) } \\
\hline \multirow[t]{2}{*}{ Age (years) } & $30.63 \pm 7.850$ & $30.86 \pm 8.669$ \\
\hline & \multicolumn{2}{|c|}{$\mathbf{N}(\%)$} \\
\hline \multicolumn{3}{|l|}{ Educational level } \\
\hline Low education & $77(64.7 \%)$ & $58(59.2 \%)$ \\
\hline High education & $42(35.3 \%)$ & $40(40.8 \%)$ \\
\hline \multicolumn{3}{|l|}{ Exercise Frequency per Week } \\
\hline $0-3$ hours & 0 & $57(58.2 \%)$ \\
\hline $3-6$ hours & $30(25.2 \%)$ & $20(20.4 \%)$ \\
\hline over 6 hours & $89(74.8 \%)$ & $21(21.4 \%)$ \\
\hline Muscle Dysmorphia Diagnoses & $4(3.4 \%)$ & 0 \\
\hline \multicolumn{3}{|l|}{ Cut-off levels } \\
\hline Dietary Behavior & $42(35.3 \%)$ & 0 \\
\hline Body size-symmetry & $21(17.6 \%)$ & $1(1 \%)$ \\
\hline Bodybuilding Dependence & $54(45.4 \%)$ & $4(4.1 \%)$ \\
\hline Physique Protection & $9(7.6 \%)$ & 0 \\
\hline Supplement Use & $42(35.3 \%)$ & $1(1 \%)$ \\
\hline Pharmacological Use & $43(36.1 \%)$ & $6(6.1 \%)$ \\
\hline
\end{tabular}

Note: $p>0.05 ; " p=0.000$.

sub-scales (Wilk's lambda $(2,214)=.827 ; \mathrm{p}=.000$ ). Subsequent univariate ANCOVA results indicate that bodybuilders, compared to non-bodybuilders athletes, report significant elevations on Dietary Behavior $\left(F_{(1}\right.$, 217) $=89.007 ; \quad \mathrm{p}=.000)$, Body size-symmetry $\left(F_{(1,217)}=54.598 ; p=.000\right)$, Bodybuilding Dependence $\left(F_{(1,217)}=44.888 ; \mathrm{p}=.000\right)$, Physique Protection $\left(\mathrm{F}_{(1}\right.$, $217)=21.840 ; p=.000)$, Supplement Use $\left(F_{(1,217)}=80.293\right.$; $p=.000)$, Pharmacological Use $\left(F_{(1,217)}=9.290 ; p=.003\right)$ scales of the MDI and on Bodybuilding Dependence $\left(F_{(1,217)}=28.245 ; \quad p=.000\right)$, Muscle Checking $\left(F_{(1}\right.$, $217)=30.564 ; p=.000)$, Substance Use $\left(F_{(1,217)}=33.251\right.$; $\mathrm{p}=.000)$, Injury $\left(\mathrm{F}_{(1,217)}=30.284 ; \mathrm{p}=.000\right)$ sub-scales of the MASS, even after controlling for effect time spend at the gym. No differences in Muscle Satisfaction scale was observed $\left(F_{(1,217)}=.059 ; p=.808\right)$ (Table 2).

ANOVA values for substance consumption and exercise frequency per week are presented in Tables $\mathbf{3}$ and 4 . The mean analyses indicate that bodybuilders who report a regular use of substance (anabolic steroid, diuretic and laxatives) or work out for more than 6 hours per week scored higher in all measures. The 2X2 analyses of variance revealed how the Substance Use scale have main effects on Dietary
Behavior $\left(F_{(1,119)}=4.991 ; p=.027\right)$, Body Size-Symmetry $\left(F_{(1,119)}=16.990 ; \quad \mathrm{p}=.000\right)$, Physique Protection $\left(F_{(1,119)}=16.292 ; \quad p=.000\right), \quad$ Supplement Use $\left(\mathrm{F}_{(1,119)}=5.522 \mathrm{p}=.020\right) \mathrm{MDI}$ scales and Body building Dependence ( $F \quad(1,119)=15.244 ; \quad \mathrm{p}=.000)$, Muscle Checking ( $F \quad\left(1,{ }_{119}=9.335 \quad \mathrm{p}=.003\right)$ and Injury $\left(F_{(1,119)}=13.719 ; \quad p=.000\right)$ MASS sub-scales. For "Exercise Frequency per Week" main effects were found for Bodybuilding Dependence $\left(F_{(1,119)}=4.938\right.$; $\mathrm{p}=.028)$ and Physique Protection $\left(\mathrm{F}_{(1,119)}=7.730\right.$ : $\mathrm{p}=.006$ ) scales of the $\mathrm{MDI}$ and Body building Dependence $\quad\left(F_{1}, \quad{ }_{119}=4.712 ; \quad p=.032\right)$, Muscle Satisfaction $\left(\mathrm{F}_{(1,119)}=4.991 ; \mathrm{p}=.027\right)$ and Injury $\left(F_{(1,119)}=3.873 ; p=.045\right)$ scales of the MASS. There were no interactions (all $p$ values $\geq$ of 0.05 ).

\section{DISCUSSION}

Our findings seem to confirm the hypothesis that competitive bodybuilding practice can be considered a risk factor for developing muscle dysmorphia if compared with regular weightlifting practice.

Four $(3.4 \%)$ of the assessed bodybuilders met the proposed diagnostic criteria for MD [2], a high 
Table 2: Multivariate Analysis of Covariance (MANCOVA) for Muscle Dysmorphia Measures

\begin{tabular}{|c|c|c|c|c|}
\hline & \multirow[b]{2}{*}{$\mathbf{F}_{(1,217)}$} & \multirow[b]{2}{*}{$p$} & \multicolumn{2}{|c|}{ Average scores } \\
\hline & & & $\begin{array}{l}\text { Bodybuilders } \\
\quad(\mathrm{N}=119)\end{array}$ & $\begin{array}{c}\text { Non-Bodybuilders } \\
(\mathrm{N}=98)\end{array}$ \\
\hline Dietary Behavior & 89.007 & .000 & 22.45 & 10.98 \\
\hline Body size-symmetry & 54.598 & .000 & 17.59 & 8.86 \\
\hline Physique Protection & 21.840 & .000 & 14.88 & 7.50 \\
\hline Supplement Use & 80.293 & .000 & 16.49 & 6.60 \\
\hline Pharmacological Use & 9.290 & .003 & 4.71 & 3.12 \\
\hline \multicolumn{5}{|l|}{ Muscle Appearance Satisfaction Scale } \\
\hline Substance Use & 33.251 & .000 & 9.73 & 5.07 \\
\hline Injury & 30.284 & .000 & 9.09 & 5.11 \\
\hline Muscle Satisfaction & .059 & .808 & 11.25 & 9.55 \\
\hline
\end{tabular}

Note: Exercise Frequency per Week as a covariate.

Table 3: Influence of Substance Use and Exercise Frequency Per Week on the Individual Muscle Dysmorphia Inventory Scales in the Bodybuilders Sample ( $N=119)$

\begin{tabular}{|c|c|c|c|c|c|c|c|}
\hline & \multicolumn{4}{|c|}{ Average Scores } & & \multirow{3}{*}{$\mathbf{F}$} & \multirow{3}{*}{$p$} \\
\hline & \multicolumn{2}{|c|}{ Substance Use } & \multicolumn{2}{|c|}{ Exercise Frequency } & & & \\
\hline & Use & No Use & 3-6 hours & over 6 hours & & & \\
\hline Dietary Behavior & 24.26 & 21.43 & 21.67 & 22.72 & SU & 4.991 & .027 \\
\hline \multirow[t]{3}{*}{ Body size-symmetry } & \multirow[t]{3}{*}{21.44} & \multirow[t]{3}{*}{15.41} & \multirow[t]{3}{*}{15.90} & \multirow[t]{3}{*}{18.16} & SU & 16.990 & .000 \\
\hline & & & & & $\mathrm{EF}$ & 2.766 & .099 \\
\hline & & & & & $S U \times E F$ & .678 & .412 \\
\hline \multirow[t]{3}{*}{ Physique Protection } & \multirow[t]{3}{*}{19.74} & \multirow[t]{3}{*}{12.13} & \multirow[t]{3}{*}{11.13} & \multirow[t]{3}{*}{16.15} & SU & 16.292 & .000 \\
\hline & & & & & $\mathrm{EF}$ & 7.730 & .006 \\
\hline & & & & & $S U \times E F$ & .254 & .615 \\
\hline \multirow[t]{3}{*}{ Supplement Use } & \multirow[t]{3}{*}{19.00} & \multirow[t]{3}{*}{15.07} & \multirow[t]{3}{*}{15.40} & \multirow[t]{3}{*}{16.85} & SU & 5.522 & .020 \\
\hline & & & & & $\mathrm{EF}$ & 1.727 & .191 \\
\hline & & & & & $S U \times E F$ & 1.422 & .235 \\
\hline
\end{tabular}

Note: $\mathrm{MDI}=$ Muscle Dysmorphia Inventory; $\mathrm{SU}=$ Substance Use; EF= Exercise Frequency per Week. 
Table 4: Influence of Substance Use and Exercise Frequency Per Week on the Individual Muscle Appearance Satisfaction Scale Scales in the Bodybuilders Sample $(\mathbf{N}=119)$

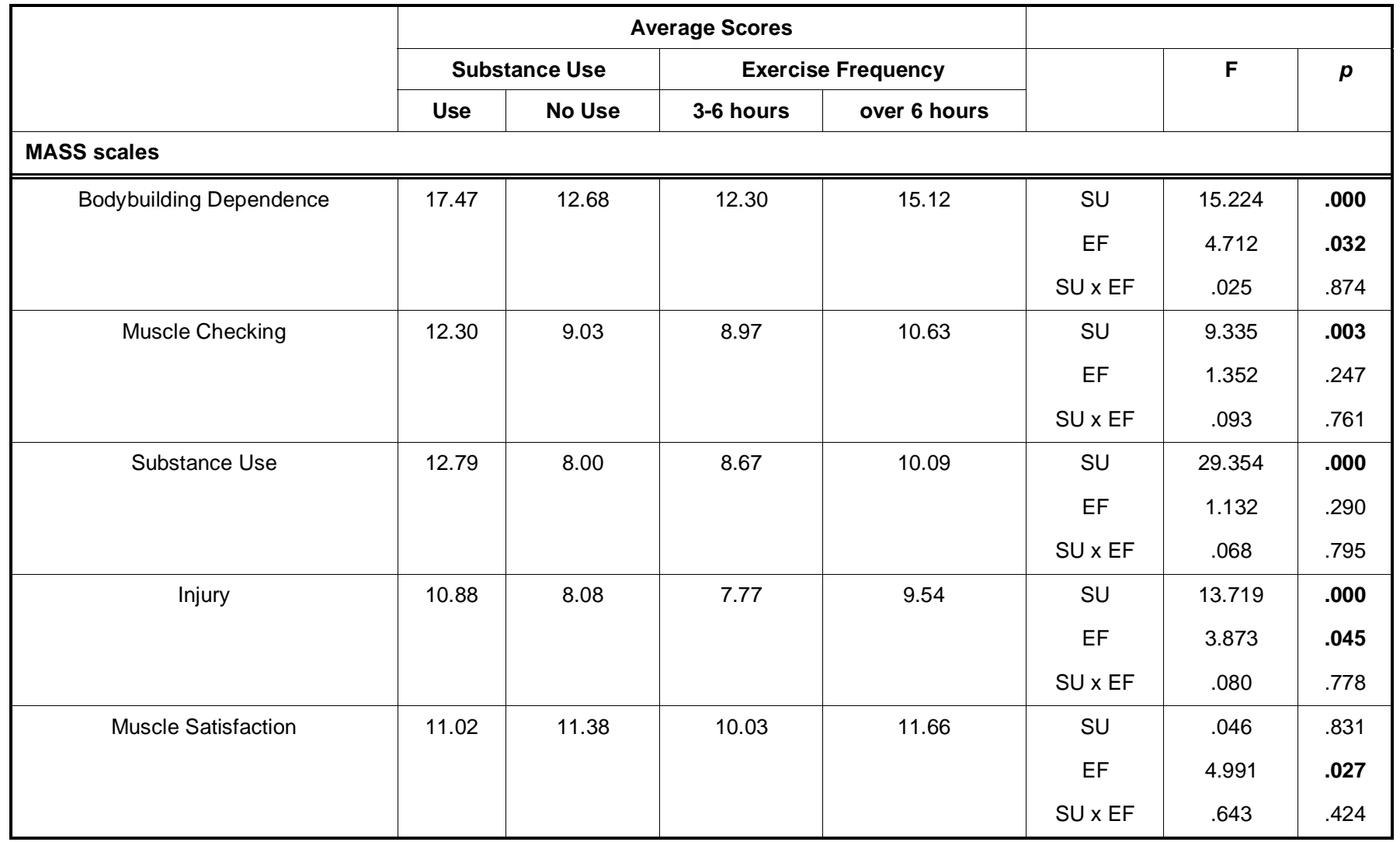

Note: $M A S S=$ Muscle Appearance Satisfaction Scale; SU= Substance Use; EF= Exercise Frequency per Week.

percentage (45.4\%) show strong dependence on exercise and significant levels of weight and shape preoccupation (17.6\%). Despite doing competitive body building, $7.6 \%$ of the athletes experience extreme anxiety and distress, as shown by the Physique Protection scale of the MDI, which go as far as total social closure and the embarrassment of being seen in public, the refusal of going to the beach and the choice of loose, heavy clothes even in summer, as a consequence of the perception of having a small and weak body.

Despite the awareness of the negative consequences on their physical or psychic health, $35.3 \%$ of bodybuilders strictly monitor food intake [15, 27], eat the same food for several days in a row and regularly use vitamin supplements (35.3\%) and drugs (36.1\%) to increase their muscular mass [28].

Even after controlling for effect time spend at the gym, male bodybuilders, compared to nonbodybuilders athletes, exhibit more severe body dissatisfaction, bodybuilding dependence and abnormal eating behaviour. They engage in harmful and unhealthy behaviours such as continuing to lift weights even when they are injured and using supplement or anabolic steroid [8].

Moreover considering only the research group, the bodybuilders who report a regular use of substance (anabolic steroid, diuretic and laxatives) or work out for more than 6 hours for week obtain higher mean values in all measures.

The time devoted to physical exercise and substance use seem to be, therefore, an important variable to differentiate bodybuilders with higher or lower dissatisfaction about their muscularity and slimness and, in our opinion, needs to be analysed in more depth.

In conclusion, these findings seem to suggest that the bodybuilding practice, even controlling by the time spent at the gym, could be considered as a risk factor for meeting Muscle Dysmorphia criteria, in particular among competitive bodybuilders who regularly use anabolic steroids [1-2, 9, 29-30].

This study is still ongoing. It is aimed at a clinical and epidemiological understanding of the 
phenomenon. Most of these subjects report sexual problems that they link to the ineffectiveness of their physical appearance, in particular to their masculinity, which seems to be characteristic of an insufficiently muscular body. The study by Mangweth et al. [15] showed that $4 \%$ of bodybuilders and $10 \%$ of the subjects diagnosed with anorexia reported a bisexual or homosexual orientation, and that $32 \%$ and $43 \%$ respectively reported a loss of sexual desire (as compared to $7 \%$ of the control sample).

Starting from those evidences in our opinion would be necessary investigate, with an appropriate procedure, any possible link between the perception of having a small and weak body, even with a muscular hypertrophy, and the strengthen of masculine identity in the bodybuilders population. And, therefore, considering the possibility that $M D$ would be the masculine variant of the feminine AN [31].

\section{REFERENCES}

[1] Pope HG Jr, Katz DL, Hudson Jl. Anorexia nervosa and "reverse anorexia" among 108 bodybuilders. Compr Psychiatry 1993; 34: 406-409.

http://dx.doi.org/10.1016/0010-440X(93)90066-D

[2] Pope HG Jr, Gruber AJ, Choi P, Olivardia R, Phillips KA. Muscle Dysmorphia. An underrecognized form of body dysmorphic disorder. Psychosomatics 1997; 38: 548-57. http://dx.doi.org/10.1016/S0033-3182(97)71400-2

[3] Hildebrandt T, Schlundt D, Langenbucher J, Chung T. Presence of muscle dysmorphia symptomology among male weightlifters. Compr Psychiatry 2006; 47: 127-35. http://dx.doi.org/10.1016/j.comppsych.2005.06.001

[4] Phillips KA, O' Sullivan RL, Pope HG Jr. Muscle Dysmorphia. J Clin Psychiatry 1997; 58: 361. http://dx.doi.org/10.4088/JCP.v58n0806a

[5] Kleiner SM, Bazzarre TL, Ainsworth BE. Nutritional status of nationally ranked elite bodybuilders. Int J Sport Nutr 1994; 4: 54-69.

[6] Pope HG, Katz DL. Psychiatric \& medical effects of anabolicandrogenic steroid use: A controlled study of 160 athletes. Arch Gen Psychiatry 1994; 51: 375-82.

http://dx.doi.org/10.1001/archpsyc.1994.03950050035004

[7] Rohman L. The relationship between anabolic androgenic steroids and muscle dysmorphia: a review. Eat Disord 2009; 17: $187-99$

http://dx.doi.org/10.1080/10640260902848477

[8] Olivardia R, Pope HG Jr, Hudson, JI. Muscle dysmorphia in male weightlifters: A case - control study. Am J Psychiatry 2000; 157: 1291-96. http://dx.doi.org/10.1176/appi.ajp.157.8.1291

[9] Blouin AG, Goldfield GS. Body image and steroid use in male bodybuilders. Int J Eat Disord 1995; 18: 159-65. http://dx.doi.org/10.1002/1098-108X(199509)18:2<159::AIDEAT2260180208>3.0.CO;2-3

[10] Olivardia R. Mirror, mirror on the wall, who's the largest of them all? The features and phenomenology of muscle dysmorphia. Harv Rev Psychiatry 2001; 9: 254-59.

[11] Pope HG Jr, Olivardia R, Phillips K. The Adonis Complex: The Secret Crisis of Male Body Obsession. New York: Free Press 2000.
Baghurst T, Lirgg C. Characteristics of muscle dysmorphia in male football, weight training, and competitive natural and non-natural bodybuilding samples. Body Image 2009; 6: 2217.

\section{http://dx.doi.org/10.1016/j.bodyim.2009.03.002}

[13] Mosley PE. Bigorexia: bodybuilding and muscle dysmorphia. Eur Eat Disord Rev 2009; 17: 191-8. http://dx.doi.org/10.1002/erv.897

[14] Lantz CD, Rhea DJ, Cornelius AE. Muscle Dysmorphia in elite - level power lifters and Bodybuilders: a test of differences within a conceptual model. J Strength Cond Res 2002; 16: 649-55.

[15] Mangweth B, Pope HG Jr, Kemmler G, et al. Body image and psychopathology in male bodybuilders. Psychother Psychosom 2001; 70: 38-43. http://dx.doi.org/10.1159/000056223

[16] Babusa B, Túry F. Muscle dysmorphia in Hungarian noncompetitive male bodybuilders. Eat Weight Disord 2012; 17: 49-53.

[17] Davis C, Scott-Robertson L. A psychological comparison of females with anorexia nervosa \& competitive male bodybuilders: body shape ideals in the extreme. Eat Behav 2000; 1 : 33-46. http://dx.doi.org/10.1016/S1471-0153(00)00007-6

[18] Goldfield GS, Blouin AG, Woodside DB. Body image, binge eating and bulimia nervosa in male bodybuilders. Can $\mathrm{J}$ Psychiatry 2006; 51: 160-68.

[19] McFarland MB, Kaminski PL. Men, muscles, and mood: the relationship between self-concept, dysphoria, and body image disturbances. Eat Behav 2009; 10: 68-70. http://dx.doi.org/10.1016/j.eatbeh.2008.10.007

[20] Lamanna J, Grieve FG, Derryberry WP, Hakman M, McClure A. Antecedents of eating disorders and muscle dysmorphia in a non-clinical sample. Eat Weight Disord 2010; 15: 23-33.

[21] Murray SB, Rieger E, Touyz SW, De la Garza García Lic Y Muscle dysmorphia and the DSM-V conundrum: where does it belong? A review paper. Int J Eat Disord 2010; 43: 483-91. http://dx.doi.org/10.1002/eat.20828

[22] Murray SB, Maguire S, Russell J, Touyz SW. The emotional regulatory features of bulimic episodes and compulsive exercise in muscle dysmorphia: a case report. Eur Eat Disord Rev 2012; 20: 68-73.

http://dx.doi.org/10.1002/erv.1088

[23] Murray SB, Rieger E, Hildebrandt T, et al. A comparison of eating, exercise, shape, and weight related symptomatology in males with muscle dysmorphia and anorexia nervosa. Body Image 2012; 9: 193-200. http://dx.doi.org/10.1016/j.bodyim.2012.01.008

[24] Pope CG, Pope HG, Menard W, Fay C, Olivardia R, Phillips KA. Clinical features of muscle dysmorphia among males with body dysmorphic disorder. Body Image 2005; 2: 395400.

http://dx.doi.org/10.1016/j.bodyim.2005.09.001

[25] American Psychiatric Association. Diagnostic and Statistical Manual of Mental Disorders: Text revision (4th ed). Washington, DC, American Psychiatric Publishing 2000.

[26] Mayville SB, Williamson DA, White MA, Netemeyer RG, Drab DL. Development of the Muscle Appearance Satisfaction Scale: a self - report measure for the assessment of Muscle Dysmorphia symptoms. Assessment 2002; 9: 351-60. http://dx.doi.org/10.1177/1073191102238156

[27] Kleiner SM, Bazzarre TL, Litchford MD. Metabolic profiles, diet and health practices of championship male and female bodybuilders. J Am Diet Assoc 1990; 90: 962-67.

[28] Brill JB, Keane MW. Supplementation patterns of competitive male and female bodybuilders. Int J Sport Nutr 1994; 4: 39812. 
[29] Kanayama G, Barry S, Hudson JI, Pope HG Jr. Body image and attitudes toward male roles in anabolic-androgenic steroid users. Am J Psychiatry 2006; 163: 697-703. http://dx.doi.org/10.1176/appi.ajp.163.4.697

[30] Pope HG Jr, Kanayama G, Hudson JI. Risk factors for illicit anabolic-androgenic steroid use in male weightlifters: a cross-sectional cohort study. Biol Psychiatry 2012; 71: 25461.

http://dx.doi.org/10.1016/j.biopsych.2011.06.024

[31] Cotrufo P. Anoressia del sessuale femminile. Dal caos alla costituzione del limite. Milano: Franco Angeli 2005.

Received on 09-08-2012

Accepted on 04-09-2012

Published on 05-10-2012

DOI: http://dx.doi.org/10.6000/1929-5634.2012.01.01.2

(C) 2012 Cella et al.; Licensee Lifescience Global.

This is an open access article licensed under the terms of the Creative Commons Attribution Non-Commercial License (http://creativecommons.org/licenses/by-nc/3.0/) which permits unrestricted, non-commercial use, distribution and reproduction in any medium, provided the work is properly cited. 